\title{
Review of Pharmacological Properties, Phytochemistry and Medicinal uses of Volkameria glabra
}

\author{
Alfred Maroyi
}

Department of Botany, University of Fort Hare, Private Bag X1314, Alice 5700, South Africa

\begin{abstract}
Volkameria glabra (E. Mey.) Mabb. \& Y.W. Yuan is a deciduous shrub or a small tree widely used as traditional medicine throughout its distributional range in tropical Africa. This study is aimed at providing a critical review of pharmacological properties, phytochemistry, and medicinal uses of $V$. glabra. Documented information on pharmacological properties, phytochemistry and medicinal uses of V. glabra was collected from several online sources such as Scopus, Google Scholar, PubMed and Science Direct, and pre-electronic sources such as book chapters, books, journal articles and scientific publications obtained from the university library. This study revealed that the bark, leaf and root infusion and/or decoction of $V$. glabra are mainly used as immune booster, protective charm, anthelmintic and ethnoveterinary medicine, and traditional medicine for convulsions, fractured bones, fever, wounds, gastro-intestinal problems, snake bite and respiratory diseases. Phytochemical compounds identified from the species include aliphatic glycosides, anthraquinones, cardiac glycosides, flavonoids, iridoid, phenols, saponins, steroids, tannins and triterpenoids. The V. glabra and compounds isolated from the species exhibited acaricidal, anthelmintic, antibacterial, antifungal, antimycobacterial, anti-collagenase, antidiabetic, anti-elastase, anti-inflammatory, antileishmanial, antioxidant, antiplasmodial, antipyretic, cholinesterase enzyme inhibition, immune-stimulant and cytotoxicity activities. Volkameria glabra should be subjected to detailed phytochemical, pharmacological and toxicological evaluations aimed at correlating its medicinal uses with its phytochemistry and pharmacological activities.
\end{abstract}

Keywords: Clerodendrum glabrum, ethnopharmacology, indigenous knowledge, Labiatae, Lamiaceae, traditional medicine, Volkameria glabra.

\section{INTRODUCTION}

Volkameria glabra (E. Mey.) Mabb. \& Y.W. Yuan is a member of the Lamiaceae, Labiatae, mint or sage family. The genus name Volkameria $\mathrm{L}$. is in honour of a German botanist Johann Georg Volckamer or Volcamer (1662-1744) [1]. The species name "glabra" is a Latin word meaning "hairless", "bald" or "smooth", in reference to the leaves that are mostly without hairs [2]. The genus Volkameria (including genus Huxleya Ewart) was recently revived by Yuan et al. [3] following phylogenetic studies, which employed chloroplast DNA regions such as trnT-L, trnL- $F$, trnD- $T$ and trnS-fM aimed at clarifying the generic boundaries of the genus Clerodendrum L. and its relationship to allied genera. As such, V. glabra has been treated as Clerodendrum glabrum E. Mey in the past and also in several recent publications [4-11]. Furthermore, V. glabra is wrongly referred to as Rotheca glabrum by Mawela et al. [12]. These observed taxonomic problems corroborate observations made by other researchers that erroneous nomenclature has a negative effect on ethnopharmacological research, threaten conservation initiatives and usage of plant genetic resources [13-17].

*Address correspondence to this author at the Department of Botany, University of Fort Hare, Private Bag X1314, Alice 5700, South Africa;

Tel/Fax: 0027719600326; E-mail: amaroyi@ufh.ac.za
Volkameria glabra is a shrub or small to mediumsized deciduous tree growing up to 10 metres in height with branches growing upwards to form a V-shaped canopy [4]. The bark of $V$. glabra is grey-brown in colour, roughly fissured or flaking with pale lenticels. The leaves are whorled or opposite, often drooping with soft hairs below and with a pungent foul smell when crushed. Flowers of $V$. glabra are white to pink in colour, foul or sweet-scented and occur in dense and rounded terminal heads. The fruits are fleshy, round, yellowish-white in colour, and surrounded by withered persistent cup-like calyx. Volkameria glabra has been recorded in the bushveld, riverine thickets, rocky hillsides, coastal dunes, forest margins, and evergreen coastal thickets. Volkameria glabra has been recorded in Angola, Botswana, the Democratic Republic of Congo (DRC), Eswatini, Kenya, Mozambique, Namibia, Somalia, South Africa, Tanzania, Seychelles and Comoros at an altitude ranging from sea level to 1600 $\mathrm{m}$ above sea level [3,5,6,8,18-27]. Synonyms associated with the name $V$. glabra include $C$. glabrum, C. capense D. Don ex Steud., C. capense Eckl. \& Zeyh. ex Schauer, C. glabratum Gürke, C. glabrum var. minutiflorum (Baker) Fosberg, C. glabrum f. pubescens R. Fern., C. minutiflorum Baker, C. ovale Klotzsch, C. ovalifolium Engl., C. rehmannii Gürke, C. somalense Chiov., Premna suaveolens Chiov. and Siphonanthus glaber (E. Mey.) Hiern. [3,5,8,19,25]. Volkameria glabra is widely used as traditional medicine in southern 
Table 1: Medicinal uses of Volkameria glabra

\begin{tabular}{|c|c|c|c|}
\hline Medicinal use & Part used & Country & Reference \\
\hline Anal prolapse & Leaves & $\begin{array}{l}\text { Eswatini and } \\
\text { South Africa }\end{array}$ & {$[37,38]$} \\
\hline Angina pain & Leaves & South Africa & {$[39,40]$} \\
\hline Anthelmintic & Bark, leaves and roots & $\begin{array}{l}\text { Eswatini, South } \\
\text { Africa and } \\
\text { Tanzania }\end{array}$ & {$[2,11,37,41,42]$} \\
\hline Anthelmintic & $\begin{array}{l}\text { Leaves mixed with those of Brachylaena discolor } \\
\text { DC., Ekebergia capensis Sparrm., Clausena } \\
\text { anisata (Willd.) Hook. f. ex Benth., Zanthoxylum } \\
\text { capense (Thunb.) Harv. and roots of Cymbopogon } \\
\text { marginatus (Steud.) Stapf ex Burtt-Davy, } \\
\text { Erythrophleum lasianthum Corbishley, Margaritaria } \\
\text { discoidea (Baill.) Webster and Hypoxis spp. }\end{array}$ & South Africa & {$[32,33]$} \\
\hline Aphonia & Leaves & South Africa & {$[40,43]$} \\
\hline Candidal infections & Bark and roots & South Africa & {$[44]$} \\
\hline Colic & Leaves & Eswatini & [37] \\
\hline Convulsions & Leaves & South Africa & {$[11,33,41]$} \\
\hline Dropsy & $\begin{array}{l}\text { Roots mixed with those of Tetradenia riparia } \\
\text { (Hochst.) Codd }\end{array}$ & South Africa & [33] \\
\hline Energy booster & $\begin{array}{l}\text { Roots mixed with those of Polianthes tuberosa L., } \\
\text { Rotheca myricoides (Hochst.) Steane \& Mabb. and } \\
\text { Senna occidentalis L. }\end{array}$ & South Africa & [28] \\
\hline Fever & Leaves and roots & $\begin{array}{l}\text { DRC and South } \\
\text { Africa }\end{array}$ & {$[33,41,45,46]$} \\
\hline Fever & $\begin{array}{l}\text { Roots mixed with those of Polianthes tuberosa, } \\
\text { Rotheca myricoides and Senna occidentalis }\end{array}$ & South Africa & [31] \\
\hline Fractured bones & Root bark & South Africa & {$[33,47,48]$} \\
\hline $\begin{array}{l}\text { Gastro-intestinal problems (bloody } \\
\text { stool and stomachache) }\end{array}$ & Leaves & $\begin{array}{l}\text { Eswatini and } \\
\text { South Africa }\end{array}$ & {$[34,49,50]$} \\
\hline Diarrhoea and bloody stool & $\begin{array}{l}\text { Leaves mixed with bark of Protorhus longifolia } \\
\text { (Bernh.) Engl. and Psidium guajava L. }\end{array}$ & South Africa & $34,35]$ \\
\hline Gastro-intestinal problems & $\begin{array}{l}\text { Roots mixed with those of Polianthes tuberosa, } \\
\text { Rotheca myricoides and Senna occidentalis }\end{array}$ & South Africa & {$[31]$} \\
\hline Immune booster & $\begin{array}{l}\text { Roots mixed with those of Polianthes tuberosa, } \\
\text { Rotheca myricoides and Senna occidentalis }\end{array}$ & South Africa & {$[28-31]$} \\
\hline Inflammation & Roots & South Africa & {$[51]$} \\
\hline Loss of appetite and weight & $\begin{array}{l}\text { Roots mixed with those of Polianthes tuberosa, } \\
\text { Rotheca myricoides and Senna occidentalis }\end{array}$ & South Africa & {$[31]$} \\
\hline Mouth ulcers & $\begin{array}{l}\text { Roots mixed with those of Polianthes tuberosa, } \\
\text { Rotheca myricoides and Senna occidentalis }\end{array}$ & South Africa & {$[31]$} \\
\hline $\begin{array}{l}\text { Protective charm (against bad luck, } \\
\text { spirits and witchcraft) }\end{array}$ & Leaves & $\begin{array}{l}\text { South Africa and } \\
\text { Zimbabwe }\end{array}$ & {$[2,33,38,48,52]$} \\
\hline Rash & Leaves & Zimbabwe & {$[52]$} \\
\hline $\begin{array}{l}\text { Respiratory diseases (asthma, chest } \\
\text { infections, colds, coughs, sinusitis, } \\
\text { sore throat and tuberculosis) }\end{array}$ & Leaves and roots & $\begin{array}{l}\text { DRC, Eswatini and } \\
\text { South Africa }\end{array}$ & $\begin{array}{l}{[2,11,33,34,37-} \\
41,45,48,53-55]\end{array}$ \\
\hline Cough & $\begin{array}{l}\text { Roots mixed with those of Polianthes tuberosa, } \\
\text { Rotheca myricoides and Senna occidentalis }\end{array}$ & South Africa & {$[31]$} \\
\hline Rheumatism & Leaves & South Africa & {$[41]$} \\
\hline Rheumatism & Roots mixed with those of Tetradenia riparia & South Africa & [33] \\
\hline Sexual dysfunction & Roots & Tanzania & {$[42]$} \\
\hline
\end{tabular}


(Table 1). Continued.

\begin{tabular}{|c|c|c|c|}
\hline Medicinal use & Part used & Country & Reference \\
\hline Snake bite & Leaves and roots & $\begin{array}{l}\text { DRC, Eswatini and } \\
\text { South Africa }\end{array}$ & {$[2,33,37,38,41,56]$} \\
\hline Toothache & Leaves & Zimbabwe & {$[52]$} \\
\hline Wasting conditions & $\begin{array}{l}\text { Roots mixed with those of Polianthes tuberosa, } \\
\text { Rotheca myricoides and Senna occidentalis }\end{array}$ & South Africa & [28] \\
\hline Wounds & Leaves & $\begin{array}{l}\text { Eswatini and } \\
\text { South Africa }\end{array}$ & {$[37,38,41]$} \\
\hline $\begin{array}{l}\text { Ethnoveterinary medicine } \\
\text { (anthelmintics, diarrhoea, purgative, } \\
\text { wounds, tick and insect-repellent) }\end{array}$ & Leaves & $\begin{array}{l}\text { DRC and South } \\
\text { Africa }\end{array}$ & $\begin{array}{c}{[2,12,33,38,41,55,57,5} \\
8]\end{array}$ \\
\hline Infertility & $\begin{array}{l}\text { Leaves mixed with those of Sansevieria pearsonii } \\
\text { N.E.Br. }\end{array}$ & Zimbabwe & {$[36]$} \\
\hline
\end{tabular}

Africa, and the species is an ingredient of some formulas, prescriptions or herbal concoctions (Table 1). In the last 20 years, several researchers conducted ethnopharmacological research on a herbal concoction known as "phela" consisting of $V$. glabra mixed with Polianthes tuberosa L. (family Asparagaceae), Rotheca myricoides (Hochst.) Steane \& Mabb. (family Lamiaceae) and Senna occidentalis L. (family Fabaceae) [28-31]. Thus, the aim of this review is to provide an integrated and detailed appraisal of the existing knowledge on the pharmacological properties, phytochemistry, and ethnomedicinal uses of V. glabra in an attempt to unravel and explore the therapeutic potential of this species.

\section{Medicinal uses}

The bark, leaf and root infusion and/or decoction of V. glabra are mainly used as an immune booster, protective charm, anthelmintic and ethnoveterinary medicine, and traditional medicine for convulsions, fractured bones, fever, wounds, gastro-intestinal problems, snake bite and respiratory diseases (Table 1; Figure 1). The leaves of $V$. glabra are mixed with those of Brachylaena discolor DC., Ekebergia capensis Sparrm., Clausena anisata (Willd.) Hook. f. ex Benth., Zanthoxylum capense (Thunb.) Harv. and roots of Cymbopogon marginatus (Steud.) Stapf ex Burtt-Davy, Erythrophleum lasianthum Corbishley, Margaritaria discoidea (Baill.) Webster and Hypoxis spp. and used as anthelmintic [32,33]. The roots of $V$. glabra are mixed with those of Tetradenia riparia (Hochst.) Codd and used as traditional medicine against dropsy [33] or mixed with roots of Polianthes tuberosa L., Rotheca myricoides (Hochst.) Steane \& Mabb. and Senna occidentalis $\mathrm{L}$. and used as an energy booster, immune booster, and a traditional medicine for gastro-intestinal

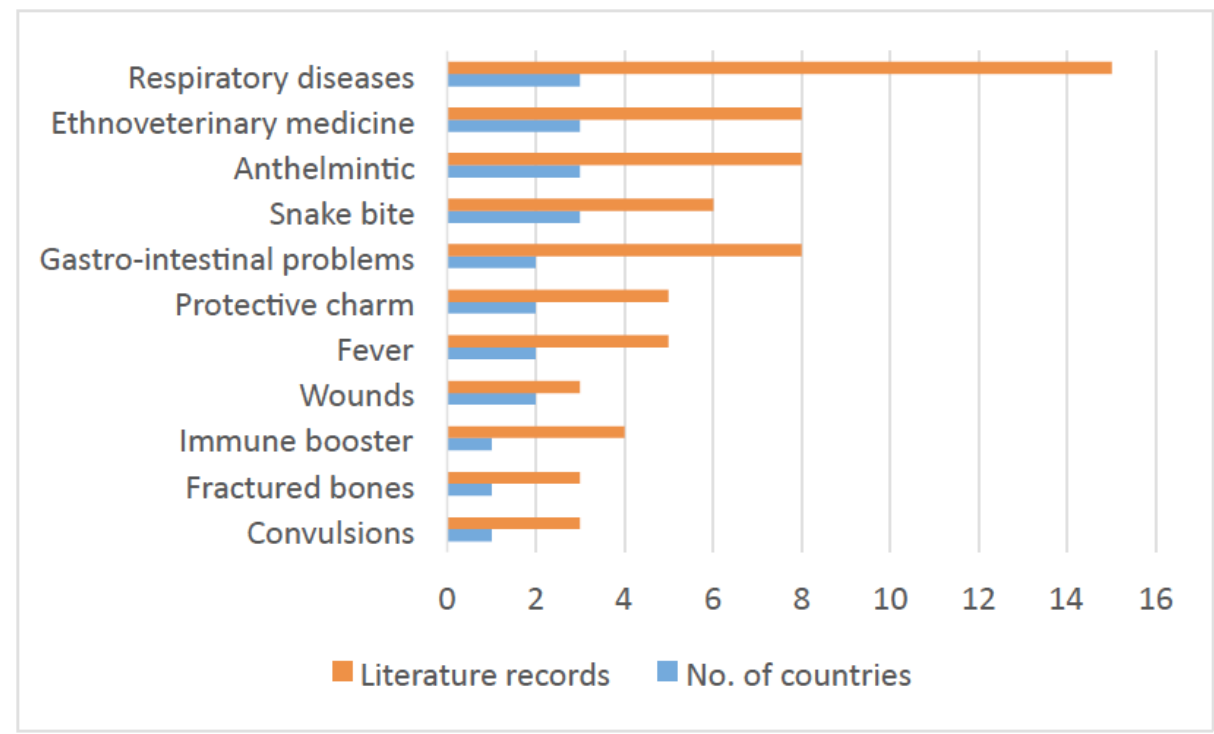

Figure 1: Medicinal applications of Volkameria glabra derived from literature records. 
problems, cough, mouth ulcers, wasting conditions, loss of appetite and weight [28-31]. The leaves of $V$. glabra are mixed with bark of Protorhus longifolia (Bernh.) Engl. and Psidium guajava L. as traditional medicine for diarrhoea and bloody stool $[34,35]$. The roots of $V$. glabra are mixed with those of Tetradenia riparia (Hochst.) Codd as a traditional medicine for rheumatism [33] and the leaves are mixed with those of Sansevieria pearsonii N.E.Br. as ethnoveterinary for infertility [36].

\section{Nutritional and Phytochemical Composition}

Wilson and Downs [59] investigated the nutritional properties of $V$. glabra fruits (Table 2). Amusan et al. [49] and Ogundajo and Ashafa [60] identified anthraquinones, cardiac glycosides, flavonoids, phenols, polyphenols, saponins, steroids, tannins and terpenoids from the leaves of $V$. glabra. From an extract of the leaves and stem bark of $V$. glabra, Fouad et al. [61], Masevhe et al. [62], Wanas et al. [63] and Teclegeorgish [64] isolated aliphatic glycosides, iridoid, phenolics, phytosterol and triterpenoids (Table 2). Some of these chemical compounds may be responsible for the biological activities of the species.

\section{Pharmacological Properties of Volkameria glabra}

The following pharmacological activities have been documented from the bark, fruits, leaves, roots and stems, and the compounds isolated from V. glabra:

Table 2: Nutritional and Phytochemical Composition of Volkameria glabra

\begin{tabular}{|c|c|c|c|}
\hline Phytochemical compound & Value & Plant part & Reference \\
\hline \multicolumn{4}{|l|}{ Nutritional components } \\
\hline Glucose $(\mathrm{mg} / \mathrm{g})$ & 55.0 & Fruits & [59] \\
\hline Fructose $(\mathrm{mg} / \mathrm{g})$ & 36.5 & Fruits & [59] \\
\hline Lipid content (\%) & 3.5 & Fruits & [59] \\
\hline Protein content $(\%)$ & 8.4 & Fruits & [59] \\
\hline Sucrose $(\mathrm{mg} / \mathrm{g})$ & 9.8 & Fruits & [59] \\
\hline Water content (\%) & 81.3 & Fruits & [59] \\
\hline \multicolumn{4}{|l|}{ Aliphatic glycosides } \\
\hline $\mathbf{N}$-butyl- $\beta$-D-fructofuranoside & - & Leaves & {$[61,63]$} \\
\hline $\mathbf{N}$-butyl- $\beta$-D-fructopyranoside & - & Leaves & {$[61,63]$} \\
\hline $\mathrm{N}$-butyl- $\alpha-\mathrm{D}$-fructofuranoside & - & Leaves & {$[61,63]$} \\
\hline \multicolumn{4}{|l|}{ Iridoid } \\
\hline 2'-O-( $\beta$-D-apiofuranosyl)-mussaenosidic acid & - & Leaves & {$[61,63]$} \\
\hline \multicolumn{4}{|l|}{ Phenolics } \\
\hline 3,5-Dimethoxy-benzoic acid & - & Leaves & {$[61,63]$} \\
\hline 3-(4-Hydroxy-3-methoxy-phenyl)-acrylic acid & - & Leaves & [63] \\
\hline Ferulic acid & - & Leaves & [61] \\
\hline \multicolumn{4}{|l|}{ Phytosterol } \\
\hline Stigmasta-5-22-dien-3 $\beta$-ol & - & Leaves and stem bark & [64] \\
\hline \multicolumn{4}{|l|}{ Triterpenoids } \\
\hline $3 \beta$-Olean-12-en3-yl palmitate & - & Leaves and stem bark & [64] \\
\hline $3 \beta$-hydroxy-5-glutinene & - & Leaves and stem bark & [64] \\
\hline $3 \beta$-lup-20(29)-en3-ol & - & Leaves and stem bark & [64] \\
\hline Clerodendrumic acid & - & Leaves & [62] \\
\hline Heptadecanoic acid & - & Leaves & [62] \\
\hline \multicolumn{4}{|l|}{ Other phytochemical compounds } \\
\hline Total flavonoid (mg quercetin/g) & $22.6-47.0$ & Leaves & [60] \\
\hline Total flavanol (mg rutin/g) & $17.9-173.7$ & Leaves & [60] \\
\hline Total phenol (mg gallic acid/g) & $61.5-66.0$ & Leaves & [60] \\
\hline
\end{tabular}


acaricidal, anthelmintic, antibacterial, antifungal, antimycobacterial, anti-collagenase, antidiabetic, antielastase, anti-inflammatory, antileishmanial, antioxidant, antiplasmodial, antipyretic, cholinesterase enzyme inhibition, immune-stimulant and cytotoxicity activities.

\section{Acaricidal Activities}

Mawela et al. [12] evaluated the acaricidal activities of methanol, acetone, dichloromethane, soap-water and water-based extracts of $V$. glabra leaves against the adult stage of the livestock tick Rhipicephalus appendiculatus with Amitix and Bayticol as positive controls. The hexane fraction from acetone extract exhibited a higher tick repellent activity than the positive controls at the same concentrations [12].

\section{Anthelmintic Activities}

McGaw et al. [65] evaluated the anthelmintic activities of hexane, ethanol and water extracts of $V$. glabra leaves on the mortality and reproductive ability of the free-living nematode Caenorhabditis elegans in two different assays. Ethanol and water extracts exhibited activities at a concentration of $1.0 \mathrm{mg} / \mathrm{ml}$ and $2.0 \mathrm{mg} / \mathrm{ml}$ after the two and seven days incubation period [65]. Adamu et al. [66] evaluated the anthelmintic activities of the acetone extract of $V$. glabra using the egg hatch assay and the larval development tests using Haemonchus contortus with albendazole as positive control. The extract exhibited activities with half maximal effective concentration $\left(E C_{50}\right)$ values of $1.5 \mathrm{mg} / \mathrm{ml}$ and $13.0 \mathrm{mg} / \mathrm{ml}$ for the egg hatch and the larval development assays, respectively [66].

\section{Antibacterial Activities}

Adamu et al. [67] evaluated the antibacterial activities of acetone extracts of $V$. glabra leaves against Staphylococcus aureus, Pseudomonas aeruginosa, Escherichia coli and Enterococcus faecalis using a serial microdilution method with gentamicin as a positive control. The extract exhibited activities with minimum inhibitory concentration (MIC) values ranging from $0.3 \mathrm{mg} / \mathrm{ml}$ to $1.3 \mathrm{mg} / \mathrm{ml}$ in comparison to a MIC value of $<0.02 \mathrm{mg} / \mathrm{ml}$ exhibited by the positive control [67]. Masevhe et al. [62] evaluated the antibacterial activities of fractions of the hexane extract of $V$. glabra leaves and the compounds clerodendrumic acid and heptadecanoic acid isolated from the species against Staphylococcus aureus, Pseudomonas aeruginosa, Enterococcus faecalis and Escherichia coli using twofold serial microdilution method with gentamicin as a positive control. Both the fractions and compounds exhibited activities with the MIC values ranging from $0.2 \mathrm{mg} / \mathrm{ml}$ to $1.3 \mathrm{mg} / \mathrm{ml}$ and $125.0 \mu \mathrm{g} / \mathrm{ml}$ to $188.0 \mu \mathrm{g} / \mathrm{ml}$, respectively [62].

\section{Antifungal Activities}

Adamu et al. [68] evaluated the antifungal activities of acetone extract of $V$. glabra leaves against Aspergillus fumigatus, Cryptococcus neoformans and Candida albicans using serial microdilution method. The extract exhibited activities with MIC values ranging from $0.04 \mathrm{mg} / \mathrm{mL}$ to $0.6 \mathrm{mg} / \mathrm{mL}$ [68]. Fouad et al. [61] evaluated the antifungal activities of the compounds $n$ butyl- $\beta$ - $D$-fructofuranoside, n-butyl- $\beta-D-$ fructopyranoside, n-butyl- $\alpha-D$-fructofuranoside, 2'-O-( $\beta$ $D$-apiofuranosyl)-mussaenosidic acid, ferulic acid and 3,5 dimethoxy benzoic acid isolated from the leaves of V. glabra against Mucor racemosus using the broth microdilution method with amphotericin $B$ as a positive control. Only compound 2'-O-( $\beta$-D-apiofuranosyl)mussaenosidic acid exhibited activities with halfmaximal inhibitory concentration $\left(\mathrm{IC}_{50}\right)$ value of 5.5 $\mu \mathrm{g} / \mathrm{ml}$ in comparison to an $\mathrm{IC}_{50}$ value of $0.4 \mu \mathrm{g} / \mathrm{ml}$ exhibited by the positive control [61]. Masevhe et al. [62] evaluated the antifungal activities of fractions of the hexane extract of $V$. glabra leaves and the compounds clerodendrumic acid and heptadecanoic acid isolated from the species against Candida albicans, Cryptococcus neoformans and Aspergillus niger using twofold serial microdilution method with amphotericin B as positive control. Both the fractions and the compounds exhibited activities with the MIC values ranging from $0.1 \mathrm{mg} / \mathrm{ml}$ to $0.6 \mathrm{mg} / \mathrm{ml}$ and 125.0 $\mu \mathrm{g} / \mathrm{ml}$ to $188.0 \mu \mathrm{g} / \mathrm{ml}$, respectively [62].

\section{Antimycobacterial Activities}

Dzoyem et al. [69] evaluated the antimycobacterial activities of acetone leaf extracts of $V$. glabra against Mycobacterium smegmatis, Mycobacterium aurum and Mycobacterium fortuitum and Mycobacterium tuberculosis using the broth microdilution method with isoniazid and rifampicin as positive controls. The extract exhibited activities against tested pathogens with the MIC values ranging from $0.2 \mathrm{mg} / \mathrm{mL}$ to 0.6 $\mathrm{mg} / \mathrm{mL}$ and total activity ranging from $7.3 \mathrm{~mL} / \mathrm{g}$ to 29.2 $\mathrm{mL} / \mathrm{g}$ [69].

\section{Anti-Collagenase Activities}

Ndlovu et al. [70] evaluated the anti-collagenase activities of methanol and ethyl acetate extracts of 
bark, fruits, roots and stems of $V$. glabra by assessing the anti-collagenase assay using the spectrophotometric methods with ethylenediaminetetraacetic acid (EDTA) as positive control. The ethyl acetate extract of the bark and stems inhibited collagenase activity by more than $80.0 \%$, which was comparable to an activity of $83.8 \%$ exhibited by the control [70].

\section{Antidiabetic Activities}

Ogundajo and Ashafa [60] evaluated the antidiabetic activities of aqueous, hexane, ethyl acetate and methanol extracts of $V$. glabra leaves using the $\alpha$ amylase inhibitory and $\alpha$-glucosidase inhibitory assays with acarbose as a positive control. The extracts exhibited activities against $\alpha$-amylase and $\alpha$ glucosidase with $\mathrm{IC}_{50}$ values ranging from $0.7 \mathrm{mg} / \mathrm{mL}$ to $2.5 \mathrm{mg} / \mathrm{mL}$ and $0.2 \mathrm{mg} / \mathrm{mL}$ to $2.8 \mathrm{mg} / \mathrm{mL}$, respectively [60].

\section{Anti-Elastase Activities}

Ndlovu et al. [70] evaluated the anti-elastase activities of methanol and ethyl acetate extracts of bark, fruits, roots and stems of $V$. glabra by assessing the anti-elastase assay using the spectrophotometric methods with N-Methoxysuccinyl-Ala-Ala-Pro-Chloro $(10.0 \mu \mathrm{g} / \mathrm{ml})$ as positive control. The ethyl acetate extract of the bark, fruits and stems inhibited elastase activity by more than $81.5 \%$ to $89.4 \%$, which was comparable to an activity of $91.5 \%$ exhibited by the control [70].

\section{Anti-Inflammatory Activities}

Jäger et al. [51] evaluated the anti-inflammatory activities of aqueous and ethanolic extracts of $V$. glabra roots in an in vitro assay for cyclooxygenase (COX) inhibitors with indomethacin $(0.5 \mu \mathrm{g})$ as a positive control. The ethanolic extract exhibited an inhibition of $88.0 \%$ which was higher than $66.5 \%$ inhibition exhibited by the indomethacin control [51]. Wahba et al. [71] evaluated the anti-inflammatory activities of the methanol and chloroform extracts of $V$. glabra leaves using the carrageenan-induced rat paw edema assay. The rat groups that received the methanol extract at an oral dose of $100.0 \mathrm{mg} / \mathrm{kg}$ body weight exhibited activities of about $56.0 \%$ to $63.0 \%$ of indomethacin after 4 hours [71].

\section{Antileishmanial Activities}

Bapela et al. [72] evaluated antileishmanial activities of dichloromethane and $50 \%$ methanol extracts of $V$. glabra leaves against axenically grown amastigote forms of Leishmania donovani following the resazurin assay protocol with miltefosine as a positive control. The dichloromethane extracts exhibited weak activities with an $\mathrm{IC}_{50}$ value of $13.4 \mu \mathrm{g} / \mathrm{ml}$ in comparison to an $\mathrm{IC}_{50}$ value of $0.2 \mu \mathrm{g} / \mathrm{ml}$ exhibited by the positive control [72].

\section{Antioxidant Activities}

Ndlovu et al. [70] evaluated the antioxidant activities of methanol and ethyl acetate extracts of the bark, fruits, roots and stems of $V$. glabra using the sodium aurothiomalate, 2,2'-azinobis-3-ethyl benzothiazoline 6sulfonic acid (ABTS) radical scavenging assay with trolox as positive control. The extract exhibited activities with an $\mathrm{IC}_{50}$ values ranging from $10.0 \mu \mathrm{g} / \mathrm{mL}$ to $63.9 \mu \mathrm{g} / \mathrm{mL}$ in comparison to an $\mathrm{IC}_{50}$ value of 2.8 $\mu \mathrm{g} / \mathrm{mL}$ exhibited by the positive control [70]. Ogundajo and Ashafa [60] evaluated the antioxidant activities of aqueous, hexane, ethyl acetate and methanol extracts of $V$. glabra leaves using ABTS, 1,1-Diphenyl-2picrylhydrazyl (DPPH) radical scavenging, metal chelation, superoxide anion scavenging capability, hydroxyl radical scavenging and ferric ions reducing power (FRAP) assays with gallic acid and silymarin as positive controls. The extracts exhibited activities in all assays with an $\mathrm{IC}_{50}$ values ranging from $0.05 \mathrm{mg} / \mathrm{mL}$ to $69.1 \mathrm{mg} / \mathrm{mL}$ in comparison to an $\mathrm{IC}_{50}$ of $0.03 \mathrm{mg} / \mathrm{mL}$ to $29.6 \mathrm{mg} / \mathrm{mL}$ exhibited by the positive control [60]. Das et al. [31] evaluated the antioxidant activities of a herbal concoction of $V$. glabra mixed with Polianthes tuberosa, Rotheca myricoides and Senna occidentalis using the DPPH free radical scavenging and hydroxyl radical scavenging assays with ascorbic acid as positive control. In DPPH, the concoction exhibited an $I_{50}$ value of $105.9 \mu \mathrm{g} / \mathrm{ml}$ in comparison to an $\mathrm{IC}_{50}$ value of $93.2 \mu \mathrm{g} / \mathrm{ml}$ exhibited by the positive control. In hydroxyl radical scavenging assay, the concoction exhibited an $\mathrm{IC}_{50}$ value of $108.0 \mu \mathrm{g} / \mathrm{ml}$ in comparison to an $\mathrm{IC}_{50}$ value of $98.7 \mu \mathrm{g} / \mathrm{ml}$ exhibited by the positive control [31].

\section{Antiplasmodial Activities}

Clarkson et al. [73] evaluated antiplasmodial activities of aqueous and dichloromethane : methanol $(1: 1)$ extracts of $V$. glabra twigs against Plasmodium falciparum using the parasite lactate dehydrogenase assay. The dichloromethane: methanol (1:1) extract exhibited weak activities with $\mathrm{IC}_{50}$ values of $19.0 \mu \mathrm{g} / \mathrm{ml}$ [73]. Bapela et al. [74,75] evaluated the antiplasmodial activities of dichloromethane and $50 \%$ methanol extracts of $V$. glabra using the $\left[{ }^{3} \mathrm{H}\right]$-hypoxanthine 
incorporation assay using chloroquine-sensitive (NF54) strain of Plasmodium falciparum as the test organism with chloroquine as positive control. The dichloromethane extract exhibited weak activities with an $\mathrm{IC}_{50}$ value of $8.9 \mu \mathrm{g} / \mathrm{ml}$ in comparison to an $\mathrm{IC}_{50}$ value of $0.003 \mu \mathrm{g} / \mathrm{ml}$ exhibited by the positive control $[74,75]$.

\section{Antipyretic Activities}

Wahba et al. [71] evaluated the antipyretic activities of the methanol and chloroform extracts of $V$. glabra leaves using the yeast-induced hyperthermia method on female Albino rats of Sprague-Dawley strain with paracetamol as the standard drug. The rat group that received methanol extract at an oral dose of 100.0 $\mathrm{mg} / \mathrm{kg}$ body weight exhibited activities of about $57.0 \%$ of paracetamol after 1 hour and about $55.0 \%$ of paracetamol activity after 2 hours [71].

\section{Cholinesterase Enzyme Inhibition Activities}

Das et al. [31] evaluated the cholinesterase enzyme inhibition activities of a herbal concoction of $V$. glabra mixed with Polianthes tuberosa, Rotheca myricoides and Senna occidentalis using a 96-well micro plate method based on Ellman's colorimetric assay with galantamine as a positive control. The concoction exhibited activities with $\mathrm{IC}_{50}$ value of $257.9 \mu \mathrm{g} / \mathrm{ml}$ in comparison to $\mathrm{IC}_{50}$ value of $20.2 \mu \mathrm{g} / \mathrm{ml}$ exhibited by the positive control [31].

\section{Immune-Stimulant Activities}

Lekhooa et al. [28] evaluated the immune-stimulant activities of a herbal concoction of $V$. glabra mixed with Polianthes tuberosa, Rotheca myricoides and Senna occidentalis by assessing the subclinical changes in Th1 cytokines (IL-2, IFN- $\gamma$ and TNF- $\alpha$ ) and Th2 cytokines (IL-4 and IL-10) in Sprague Dawley rats. The rats were treated daily and separately with normalsaline, cyclosporine-A, extract only and extract + cyclosporine-A, and after 7 and 14 days of treatment, the serum Th1 cytokines and Th2 cytokines were measured by ELISA. The extract did not stimulate Th1 cytokines of a normal immune system but stimulated them when the immune system was suppressed by cyclosporine-A [28]. Lekhooa et al. [30] evaluated the immune-stimulant activities of a herbal concoction of $V$. glabra mixed with Polianthes tuberosa, Rotheca myricoides and Senna occidentalis by assessing the effect of the extract on cyclosporine A, cyclophosphamide and dexamethasone induced immunosuppression in Sprague Dawley rats. The effective dose of the extract was determined to be 15.4 $\mathrm{mg} / \mathrm{kg} / \mathrm{day}$, which led to a moderate increase in the immune parameters in the normal rats [30].

\section{Cytotoxicity Activities}

Adamu et al. [66] evaluated the cytotoxicity activities of acetone extract of $V$. glabra against African Green Monkey kidney (Vero) cells using the tetrazolium-based colorimetric MTT (3-5-dimethyl thiazol-2-yl-2, 5diphenyl tetrazolium bromide) assay. The extract exhibited activities with half maximal lethal concentration $\left(\mathrm{LC}_{50}\right)$ value of $0.04 \mathrm{mg} / \mathrm{ml}$ [66]. Adamu et al. [68] evaluated the cytotoxicity activities of acetone extracts of $V$. glabra leaves against Vero monkey kidney cells using the tetrazolium-based colorimetric MTT assay. The extract exhibited activities with half maximal lethal dose $\left(L_{50}\right)$ value of $0.2 \mathrm{mg} / \mathrm{mL}$ [68]. Fouad et al. [61] evaluated the cytotoxicity activities of the compounds $n$-butyl- $\beta-D-$ fructofuranoside, $n$-butyl- $\beta$ - $D$-fructopyranoside, $n$-butyl$\alpha$-D-fructofuranoside, $\quad 2$-O-( $\beta$-D-apiofuranosyl)mussaenosidic acid, ferulic acid and 3,5 dimethoxy benzoic acid isolated from the leaves of $V$. glabra against the human lung cancer cell line A549 using the MTT assay. Only compound 2'-O-( $\beta$-D-apiofuranosyl)mussaenosidic acid exhibited activities with an $\mathrm{IC}_{50}$ value of $51.1 \mu \mathrm{g} / \mathrm{ml}$ [61]. Bapela et al. [72,74,75] evaluated the cytotoxicity activities of dichloromethane and $50 \%$ methanol extract of $V$. glabra leaves against mammalian L-6 rat skeletal myoblast cells with podophyllotoxin as positive control. The dichloromethane and $50 \%$ methanol extracts exhibited $\mathrm{IC}_{50}$ values of $62.2 \mu \mathrm{g} / \mathrm{ml}$ and $72.7 \mu \mathrm{g} / \mathrm{ml}$, respectively, which were considered to be non-toxic to rat skeletal myoblast L6 cells [72,74,75]. Dzoyem et al. [69] evaluated the cytotoxicity activities of acetone leaf extracts of $V$. glabra against Vero cells using the MTT assay with doxorubicin as a positive control. The extract exhibited the $\mathrm{LC}_{50}$ value of $357.1 \mu \mathrm{g} / \mathrm{mL}$ in comparison to the $\mathrm{LC}_{50}$ value of $4.5 \mu \mathrm{g} / \mathrm{mL}$ exhibited by the positive control, implying that the plant extracts screened could be considered as relatively safe [69]. Mehrbod et al. [76] evaluated the cytotoxicity activities of methanol extracts of $V$. glabra leaves against MDCK cells using the MTT assay. The extract exhibited activities with half maximal cytotoxic concentration $\left(\mathrm{CC}_{50}\right)$ value of $221.0 \mu \mathrm{g} / \mathrm{ml}$ [76]. Ogundajo and Ashafa [60] evaluated the cytotoxicity activities of aqueous, hexane, ethyl acetate and methanol extracts of $V$. glabra leaves against the Vero monkey kidney cells using the tetrazolium-based colorimetric assay (MTT assay). The extracts exhibited activities with the $\mathrm{LC}_{50}$ values ranging from $0.1 \mathrm{mg} / \mathrm{mL}$ to $0.5 \mathrm{mg} / \mathrm{mL}$ [60]. 


\section{CONCLUSION}

Research on $V$. glabra over the past decades showed that the species is an important traditional medicine in east, central and southern Africa. The species is also an ingredient of some formulas, prescriptions or herbal concoctions. Therefore, future research should also evaluate the combinational, additive, and synergetic effects associated with complex herbal concoctions that have $V$. glabra as an ingredient. These evaluations should aim at correlating the medicinal uses of the species with its phytochemistry and pharmacological activities.

\section{REFERENCES}

[1] Quattrocchi U. CRC World dictionary of palms: common names, scientific names, eponyms, synonyms, and etymology volume iv R-Z. Washington DC: CRC Press; 1999.

[2] Thomas V, Grant R. Sappi tree spotting: KwaZulu-Natal and Eastern Cape. Johannesburg: Jacana Media (Pty) Ltd; 2013.

[3] Yuan $Y-W$, et al. Further disintegration and redefinition of Clerodendrum (Lamiaceae): Implications for the understanding of the evolution of an intriguing breeding strategy. Taxon 2010; 59(1): 125-33. https://doi.org/10.1002/tax.591013

[4] Palgrave MC. Keith Coates Palgrave trees of southern Africa. Cape Town: Struik Publishers, 2002.

[5] Germishuizen G and Meyer NL. Plants of southern Africa: An annotated checklist. Pretoria: Strelitzia 14, National Botanical Institute, 2003.

[6] Fernandes R, Diniz M.A. Avicenniaceae, Nesogenaceae, Verbenaceae and Lamiaceae (subfamalies, Viticoideae and Ajugoideae) Flora Zambesiaca 8(7). Richmond: Royal Botanic Gardens, Kew, 2005

[7] Bandeira S, Bolnick D, Barbosa F. Wild flowers of southern Mozambique. Maputo: Universidade Eduardo Mondlane, 2007.

[8] Figueiredo E, Smith GF. Plants of Angola. Pretoria: Strelitzia 22, South African National Biodiversity Institute, 2008.

[9] Quattrocchi U. CRC world dictionary of medicinal and poisonous plants: Common names, scientific names, eponyms, synonyms, and etymology. Washington DC: CRC Press, 2012.

[10] Koekemoer M, Steyn HM, Bester SP. Guide to plant families of southern Africa. Pretoria: Strelitzia 31, South African National Biodiversity Institute, 2014.

[11] Schmidt E, Lotter M, McCleland W. Trees and shrubs of Mpumalanga and Kruger National Park. Johannesburg: Jacana Media, 2017.

[12] Mawela KG, et al. Repellent properties of Rotheca glabrum plant extracts against adults of Rhipicephalus appendiculatus. BMC Vet Res 2019; 15: 122. https://doi.org/10.1186/s12917-019-1853-5

[13] Rivera D, et al. What is in a name? The need for accurate scientific nomenclature for plants. J Ethnopharmacol 2014; 152: 393-402.

https://doi.org/10.1016/j.jep.2013.12.022

[14] Dauncey EA, et al. Common mistakes when using plant names and how to avoid them. European J Integrative Med 2016; 8: 597-601. https://doi.org/10.1016/j.eujim.2016.09.005

[15] Ghorbani A, Saeedi Y, De Boer HJ. Unidentifiable by morphology: DNA barcoding of plant material in local markets in Iran. PLoS One 2017; 12(4): e0175722.

https://doi.org/10.1371/journal.pone.0175722
[16] Guzzon F, Ardenghi NMG. Could taxonomic misnaming threaten the ex situ conservation and the usage of plant genetic resources? Biod Cons 2018; 27: 1157-72. https://doi.org/10.1007/s10531-017-1485-7

[17] Sharma V, Restrepo MI, Sarkar IN. Solr-plant: efficient extraction of plant names from text. BMC Bioinform 2019; 20: 263. https://doi.org/10.1186/s12859-019-2874-6

[18] Drummond RB. A list of trees, shrubs and woody climbers indigenous or naturalised in Rhodesia. Kirkia 1975; 10(2): 229-85.

[19] Verdcourt B. Clerodendrum. In Polhill RM (Ed.), Flora of tropical East Africa: Verbenaceae. Rotterdam: Balkema, 1992, pp. 84-144.

[20] Setshogo MP, Venter F. Trees of Botswana: Names and distribution. Pretoria: Southern African Botanical Diversity Network Report No. 18, 2003.

[21] Da Silva MC, Izidine S, Amude AB. A preliminary checklist of the vascular plants of Mozambique. Pretoria: Southern African Botanical Diversity Network Report No. 30, 2004.

[22] Mapaura A, Timberlake J. A checklist of Zimbabwean vascular plants. Pretoria: Southern African Botanical Diversity Network Report No. 33, 2004.

[23] Loffler L, Loffler P. Swaziland tree atlas: Including selected shrubs and climbers. Pretoria: Southern African Botanical Diversity Network Report No. 38, 2005.

[24] Setshogo MP. Preliminary checklist of the plants of Botswana. Pretoria: Southern African Botanical Diversity Network Report No. 37, 2005

[25] Thulin M. Flora of Somalia 3. Richmond: The Royal Botanic Gardens, Kew, 2006.

[26] Van Wyk B, Van Wyk P. Field guide to trees of southern Africa. Cape Town: Struik Nature, 2013.

[27] Burrows JE, et al. Trees and shrubs of Mozambique. Cape Town: Publishing Print Matters (Pty), 2018.

[28] Lekhooa $\mathrm{M}$, et al. Evaluation of traditional medicines iii: The mechanism of immune modulation by PHELA. Afr J Trad Compl Alt Med 2012; 9(5S): 47-63 https://doi.org/10.4314/aitcam.v9i3S.7

[29] Lekhooa M, et al. Evaluation of traditional medicines ii: the use of metabolite peak-kinetics to monitor phela in rat plasma. Afr J Trad Compl Alt Med 2012; 9(3S): 73-80. https://doi.org/10.4314/ajtcam.v9i3S.7

[30] Lekhooa MR, et al. The development and use of a druginduced immunosuppressed rat-model to screen Phela for mechanism of immune stimulation. J Ethnopharmacol 2017; 206: 8-18.

https://doi.org/10.1016/j.jep.2017.04.031

[31] Das B, et al. Anti-cholinesterase potential of standardized extract of phela a traditional South African medicine formulation. J Herbal Med 2020. https://doi.org/10.1016/j.hermed.2020.100348

[32] Bryant AT. Zulu Medicine and medicine-men. Cape Town: C Struik, 1966.

[33] Hutchings A, et al. Zulu medicinal plants: An inventory. Pietermaritzburg: University of Natal Press, 1996.

[34] Bisi-Johnson MA, et al. A survey of indigenous herba diarrhoeal remedies of O.R. Tambo district, Eastern Cape Province, South Africa. Afr J Biot 2010; 9(8): 1245-54. https://doi.org/10.5897/AJB09.1475

[35] Maroyi A. Review of medicinal uses, phytochemistry and pharmacological properties of Protorhus longifolia. J Pharmaceut Sci Res 2019; 11(8): 3072-9. https://doi.org/10.3390/nu11030545

[36] Takawira-Nyenya R, Stedje B. Ethnobotanical studies in the genus Sansevieria Thunb. (Asparagaceae) in Zimbabwe. Ethnobot Res Appl 2011; 9: 421-43. https://doi.org/10.17348/era.9.0.421-443 
[37] Long C. Swaziland's flora: siSwati names and uses. Mbambane, Swaziland: Swaziland National Trust Commission; 2005. Available at: http://www .sntc.org.sz/index.asp, accessed on 14 February 2020.

[38] Nenungwi S. Clerodendrum glabrum E. Mey. var. glabrum; 2012. Available at: http://pza.sanbi.org/clerodendronglabrum, accessed on 23 March 2020.

[39] Semenya SS, Maroyi A. Ethnobotanical survey of plants used by Bapedi traditional healers to treat tuberculosis and its opportunistic infections in the Limpopo Province, South Africa. S Afr J Bot 2019; 122: 401-21. https://doi.org/10.1016/j.sajb.2018.10.010

[40] Semenya SS, Maroyi A. Source, harvesting, conservation status, threats and management of indigenous plant used for respiratory infections and related symptoms in the Limpopo Province, South Africa. Biodiversitas 2019; 20(3): 790-811. https://doi.org/10.13057/biodiv/d200325

[41] Watt JM, Breyer-Brandwijk MG. The medicinal and poisonous plants of southern and eastern Africa. London: Livingstone, 1962.

[42] Luoga EJ, Witkowski ETF, Balkwill K. Differential utilization and ethnobotany of trees in Kitulanghalo Forest Reserve and surrounding communal lands, eastern Tanzania. Econ Bot 2000; 54(3): 328-43.

https://doi.org/10.1007/BF02864785

[43] Semenya SS, Maroyi A. Therapeutic plants used by traditional health practitioners to treat pneumonia in the Limpopo Province, South Africa. Latin American Caribb Bull Med Aromatic PI 2018; 17(6): 583-603.

[44] Masevhe NA, McGaw LJ, Eloff JN. The traditional use of plants to manage candidiasis and related infections in Venda, South Africa. J Ethnopharmacol 2015; 168: 364-72. https://doi.org/10.1016/j.jep.2015.03.046

[45] Von Koenen E. Medicinal, poisonous, and edible plants in Namibia. Windhoek: Klaus Hess Publishers, 2001.

[46] Fowler DG. Traditional fever remedies: A list of Zambian plants. London: Royal Botanic Gardens, Kew, 2006.

[47] Arnold H-J, Gulumian M. Pharmacopoeia of traditional medicine in Venda. J Ethnophannacol 1984; 12: 35-74. https://doi.org/10.1016/0378-8741(84)90086-2

[48] Mabogo DEN. The Ethnobotany of the VhaVenda. MSc Dissertation. Pretoria: University of Pretoria, 1990.

[49] Amusan OOG, et al. Some Swazi phytomedicines and their constituents. Afr J Biotech 2007; 6(3): 267-72.

[50] Amusan OOG. Herbal medicine in Swaziland: An overview. In Juliani HR, Simon JE, Ho C-T (Editors), African natural plant products: New discoveries and challenges in chemistry and quality. Washington DC: American Chemical Society, 2010, pp. 31-49. https://doi.org/10.1021/bk-2009-1021.ch003

[51] Jäger AK, Hutchings A, Van Staden J. Screening of Zulu medicinal plants for prostaglandin-synthesis inhibitors. J Ethnopharmacol 1996; 52: 95-100.

https://doi.org/10.1016/0378-8741(96)01395-5

[52] Gelfand $M$, et al. The traditional medical practitioner in Zimbabwe: His principles of practice and pharmacopoeia. Gweru: Mambo Press, 1985.

[53] Semenya SS, Maroyi A. Medicinal applications of plants by Bapedi traditional healers for sore throat and related symptoms in the Limpopo Province, South Africa. Med Plants Int J Phytomed Related Indust 2018; 10(4): 261-80. https://doi.org/10.5958/0975-6892.2018.00048.5

[54] Semenya SS, Maroyi A. Plants used by Bapedi traditional healers to treat asthma and related symptoms in Limpopo province, South Africa. Evidence-Based Compl Alt Med 2018; article ID 2183705 https://doi.org/10.1155/2018/2183705

[55] Semenya SS, Maroyi A. Source of plants, used by Bapedi traditional healers for respiratory infections and related symptoms in the Limpopo Province, South Africa. J Biol Sci 2019; 19(2): 101-21.

https://doi.org/10.3923/jbs.2019.101.121

[56] Roberts M. Indigenous healing plants. Johannesburg: Southern Book Publishers, 1990

[57] Matlebyane MM, Ng'ambi JWW, Aregheore EM. Indigenous knowledge (IK) ranking of available browse and grass species and some shrubs used in medicinal and ethnoveterinary practices in ruminant livestock production in Limpopo province, South Africa. Livest Res Rural Develop 2010; 22: 3.

[58] Mphahlele $\mathrm{M}$, et al. In vitro anthelmintic activity of aqueous extracts of five medicinal plant against eggs and the infective stage of Haemonchus contortus. Livest Res Rural Develop 2016; 28: 12.

[59] Wilson A-L, Downs CT. Fruit nutritional composition and nonnutritive traits of indigenous South African tree species. S Afr J Bot 2012; 78: 30-6. https://doi.org/10.1016/j.sajb.2011.04.008

[60] Ogundajo AL, Ashafa AOT. Medicinal properties of Clerodendrum glaburum E may leaf extracts: phytochemical constituents, antioxidant, cytotoxicity, and carbohydratemetabolizing enzyme inhibitory potentials. Comparative Clin Pathol 2019; 28: 927-36. https://doi.org/10.1007/s00580-018-2825-z

[61] Fouad MA, Wanas AS, Khalil HE. Phytochemical and biological studies of Clerodendrum glabraum leaves. Int $\mathrm{J}$ Pharmacogn Phytochem 2013; 28(2): 1164-8.

[62] Masevhe NA, et al. Clerodendrumic acid, a new triterpenoid from Clerodendrum glabrum (Verbenaceae), and antimicrobial activities of fractions and constituents. Helvetica 2013; 96(9): 1693-703. https://doi.org/10.1002/hlca.201200552

[63] Wanas AS, et al. Phytochemical study of the leaves of Clerodendrum glabrum (Verbenaceae). PI Med 2013; 79: 76. https://doi.org/10.1055/s-0033-1348757

[64] Teclegeorgish ZW. Phytochemical investigations of Moringa oleifera and Clerodendrum glabrum. MSc Dissertation. Pretoria: Tshwane University of Technology, 2017.

[65] McGaw LJ, Jager AK, Van Staden J. Antibacterial, anthelmintic and antiamoebic activity in South African medicinal plants. J Ethnopharmacol 2000; 72: 247-63. https://doi.org/10.1016/S0378-8741(00)00269-5

[66] Adamu M, Naidoo V, Eloff JN. Efficacy and toxicity of thirteen plant leaf acetone extracts used in ethnoveterinary medicine in South Africa on egg hatching and larval development of Haemonchus contortus. BMC Vet Res 2013; 9: 38. https://doi.org/10.1186/1746-6148-9-38

[67] Adamu M, Naidoo V, Eloff JN. The antibacterial activity, antioxidant activity and selectivity index of leaf extracts of thirteen South African tree species used in ethnoveterinary medicine to treat helminth infections. BMC Vet Res 2014; 10: 52. https://doi.org/10.1186/1746-6148-10-52

[68] Adamu M, Naidoo V, Eloff JN: Some southern African plant species used to treat helminth infections in ethnoveterinary medicine have excellent antifungal activities. BMC Compl Alt Med 2012; 12: 213.

https://doi.org/10.1186/1472-6882-12-213

[69] Dzoyem JP, et al. Antimycobacterial activity against different pathogens and selectivity index of fourteen medicinal plants used in southern Africa to treat tuberculosis and respiratory ailments. S Afr J Bot 2016; 102: 70-4. https://doi.org/10.1016/j.sajb.2015.08.002

[70] Ndlovu G, et al. In vitro determination of the anti-aging potential of four southern African medicinal plants. BMC Compl Alt Med 2013; 13: 304.

https://doi.org/10.1186/1472-6882-13-304

[71] Wahba HM, et al. Chemical and biological investigation of some Clerodendrum species cultivated in Egypt. Pharm Biol 2011; 49(1): 66-72.

https://doi.org/10.3109/13880209.2010.494674 
[72] Bapela MJ, Kaiser M, Meyer JJM. Antileishmanial activity of selected South African plant species. S Afr J Bot 2017; 108: 342-5. https://doi.org/10.1016/j.sajb.2016.08.014

[73] Clarkson C, et al. In vitro antiplasmodial activity of medicinal plants native to or naturalised in South Africa. J Ethnopharmacol 2004; 92: 177-91. https://doi.org/10.1016/j.jep.2004.02.011

[74] Bapela JM, Meyer JJM, Kaiser M. In vitro antiplasmodial screening of ethnopharmacologically selected South African plant species used for the treatment of malaria. J Ethnopharmacol 2014; 156: 370-3. https://doi.org/10.1016/j.jep.2014.09.017
[75] Bapela MJ, et al. ${ }^{1} \mathrm{H}$ NMR-based metabolomics of antimalarial plant species traditionally used by Vha-Venda people in Limpopo Province, South Africa and isolation of antiplasmodial compounds. J Ethnopharmacol 2019; 228 : 148-55. https://doi.org/10.1016/j.jep.2018.07.022

[76] Mehrbod $P$, et al. South African medicinal plant extracts active against influenza A virus. BMC Compl Alt Med 2018; 18: 112. https://doi.org/10.1186/s12906-018-2184-y

DOI: https://doi.org/10.29169/1927-5951.2020.10.05.12

(C) 2020 Alfred Maroyi; Licensee SET Publisher.

This is an open access article licensed under the terms of the Creative Commons Attribution Non-Commercial License (http://creativecommons.org/licenses/by-nc/3.0/) which permits unrestricted, non-commercial use, distribution and reproduction in any medium, provided the work is properly cited. 